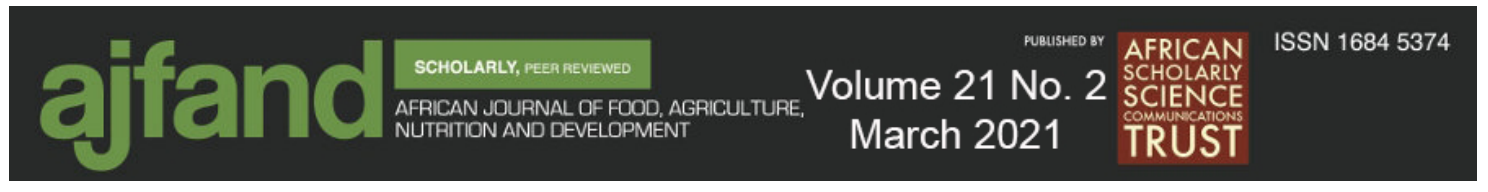

Afr. J. Food Agric. Nutr. Dev. 2021; 21(2): 17450-17463

https://doi.org/10.18697/ajfand.97.19410

\title{
FARM HOUSEHOLDS' LEVELS OF VULNERABILITY TO EXTREME WEATHER EVENTS IN SOUTH-EASTERN NIGERIA
}

Obi $\mathrm{JN}^{1 *}$, Enete $\mathrm{AA}^{1}$ and $\mathrm{JO}$ Munonye ${ }^{2}$

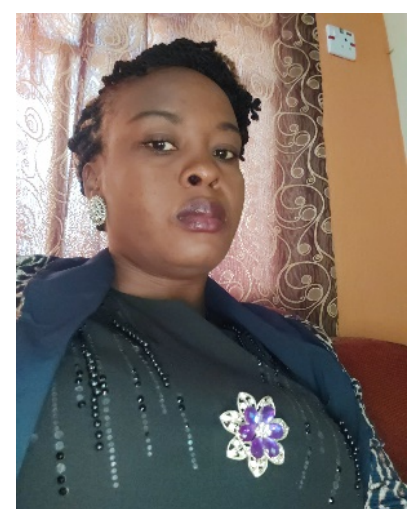

Obi Joy

*Corresponding author email: jnamaka1@yahoo.com

${ }^{1}$ Department of Agricultural Economics, University of Nigeria, Nsukka, Nigeria

${ }^{2}$ Department of Agriculture (Agricultural Economics and Extension Programme), Alex Ekwueme Federal University Ndufu-Alike, Ebonyi State, Nigeria 


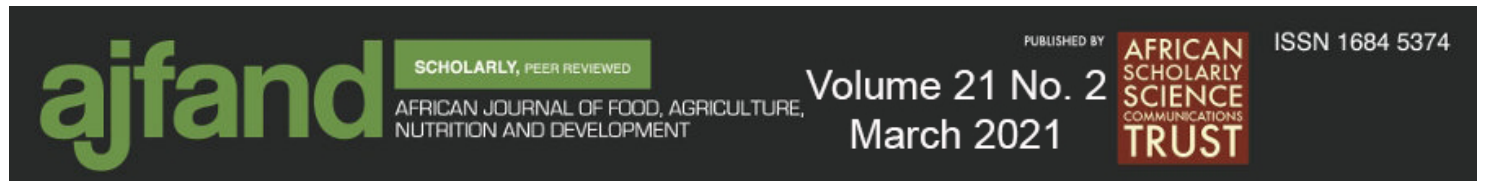

\begin{abstract}
The impacts of climate change risks, risk management mechanisms and the physical environment under which farm households operate play significant roles in poverty and hidden hunger dynamics in developing countries. Extreme weather events are most often triggers of changes in risk management, which also affect the capacity of households to absorb the resultant shocks. This paper based on primary data collected as part of a $\mathrm{PhD}$ dissertation in the Department of Agricultural Economics, University of Nigeria, Nsukka, presents an analysis of farm households' levels of vulnerability to extreme weather events in South-eastern Nigeria. A multistage sampling procedure was used in the selection of 120 male- and 120 female-headed farm households that constituted the sample for the study. Both structured interview schedule and focus group discussion guide were used to gather data from the respondents, which were analyzed using UNDP vulnerability index. Using household adaptive capacity approach, data were collected on human, economic and institutional capacity of farmers in coping with extreme weather events. Female-headed households were more vulnerable than their male-headed counterparts to the effect of extreme weather events with respect to some of the indicators such as farming income, years of formal education, farm size, land ownership status, number of extension contacts, access to weather information, access to remittance, membership of cooperative and assistance from National Emergency Management Agency in the area. Overall, using household adaptive capacity approach, the results of the gender- based vulnerability analysis showed male-headed farming households with a vulnerability index of 0.38 while the female-headed farming households, on the other hand, had vulnerability index of 0.68 . Although female-headed farm households were more vulnerable than their male counterparts, the farmers were all generally highly vulnerable to the incidence of natural disasters because of low adaptive capacity. The study recommends that government and development partners with the responsibility of protecting the environment should be gender sensitive and redirect more effort in mitigating the negative agricultural effects caused by extreme weather events, especially among female-headed farm households who are more vulnerable.
\end{abstract}

Key words: Nigeria Climate change, Adaptive capacity, Gender, Vulnerability, Farm households. 


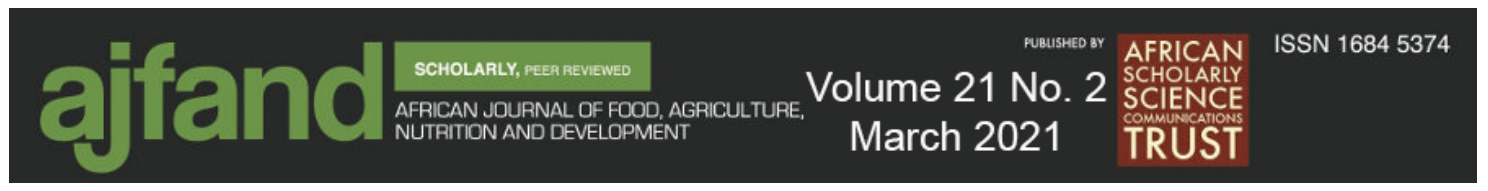

\section{INTRODUCTION}

Climate change is one of the worst environmental, social and economic threats facing mankind across every endeavor. This is particularly true for agriculture because of its direct impact on food productivity [1,2]. This assertion is consistent with the observation made by the Inter-governmental Panel on Climate Change [3] that agriculture is highly vulnerable to the increased frequency, severity and unpredictability of extreme weather-related events.

According to the Intergovernmental Panel on Climate Change report [3], Nigeria, like many other countries in sub-Saharan Africa, by virtue of its location within the tropical latitude has been severely exposed to destructive influences of climate-induced hazards. According to Anthony [4], Nigeria remains one of the most vulnerable countries to flooding because of low adaptive capacity. This is because of the country's dependence on natural resources, such that rising temperature and other extreme weather events put pressure on food security [5]. South-east Nigeria is downstream of both rivers Niger and Benue. It is, therefore, vulnerable to extreme weather events and always hard hit. The report of the studies of FAO [1] and (IPCC) [3] showed that rising sea level will affect the livelihoods of a large percentage of populations that live in the South-east areas. Consequently, livelihood may be at great risk in these regions due to erosion and flooding. As South-east continues to be hit by massive flooding, erosion, extreme heat, food production will be affected; the relevant question is "what is the level of vulnerability of farm households to these unprecedented extreme weather events?".

The characteristics and enormity of risks that households face, the access to risk management mechanisms and the environment in which households operate their activities, play a significant role in poverty dynamics [1]. Measurement of vulnerability would be a positive approach to think about forward looking anti-poverty interventions, by explaining, who (men or women) are prone to be poor in terms of adaptive capacity indicators. Therefore, the objective of this study was to assess farm households' levels of vulnerability to extreme weather events using adaptive capacity indicators.

\section{METHOD OF THE STUDY}

\section{The Study area}

The study was conducted in South-eastern Nigeria. Nigeria is at borders of Gulf of Guinea on the south, Cameroon and Chad on the east, Niger on the north and Benin on the west. With a total of 923,768 square kilometers of space, the country has an estimated population of 206,139,589 individuals and a population growth of 2.58 percent annually [6]. The South-east Nigeria agro-ecological zone is made up of five states, namely, Abia, Anambra, Ebonyi, Enugu and Imo and has a rural population density of 173 persons per square kilometer. Anambra State lies between latitudes $5^{\circ}$ $40^{\prime} 00^{\prime \prime} \mathrm{N}$ and $6^{\circ} 50^{\prime} 00^{\prime \prime} \mathrm{N}$ and longitudes $6^{\circ} 40^{\prime} 00^{\prime \prime} \mathrm{E}$ and $7^{\circ} 20^{\prime} 00^{\prime \prime} \mathrm{E}$, while Ebonyi State lies between latitudes $6^{\circ} 10^{\prime} 40^{\prime \prime} \mathrm{N}$, and longitudes $7^{\circ} 57^{\prime}$ and $33^{\prime \prime} \mathrm{E}$ and Enugu State lies between latitudes $6^{\circ} 27^{\prime} 35^{\prime \prime} \mathrm{N}$, and longitudes $7^{\circ} 32^{\prime}$ and $21^{\prime \prime} \mathrm{E}(6)$. The zone has a total land mass of $10,952,400$ hectares with over 16 million resident population [6]. By virtue of the location of South-east States within the tropical latitude, they are 


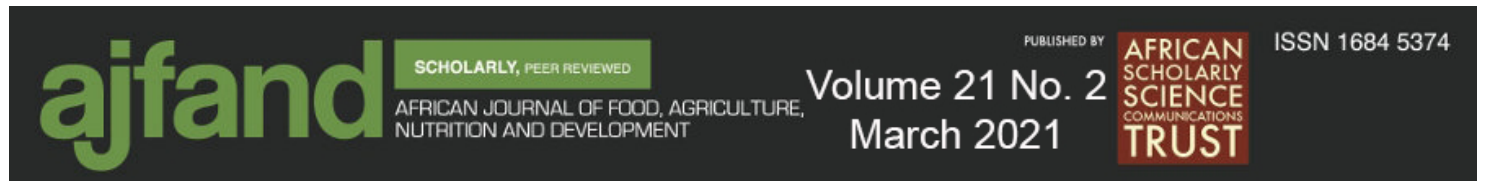

severely exposed to destructive influences of climate change induced hazards such as flood, erosion, drought and severe heat waves [1]. The states comprise of numerous thickly populated villages, a number of small towns and a few major towns with some areas thickly populated.

\section{Sampling procedure and data}

The study was restricted to the south-eastern Nigeria geo-political zone, comprising of Abia, Anambra, Ebonyi and Imo (6). Three states, Enugu, Anambra and Ebonyi were randomly selected. The choice of the states was informed by the intense extreme weather events such as flooding and erosion farm households' face, which disrupt farming activities; two agricultural zones were purposively selected based on predominance of flood and erosion disasters in the area. These were Enugu and Nsukka in Enugu State, Anambra and Awka in Anambra, Ebonyi North and Ebonyi Central in Ebonyi State. In each agricultural zone and with the assistance of extension services Department, farming communities were compiled, from which two communities were randomly selected making a total of twelve communities. The communities were Obollo-Eke, Udi, Nsukka, Uzo-Uwani in Enugu; Anyamelu, Oyi, Anaocha, Anambra west in Anambra; Ohaukwu, Ebonyi, Izzi, and Ikwo in Ebonyi. A total of 120 maleand 120- female-headed farm households constituted the samples for the study.

A structured survey instrument was then developed and pre-tested in a pilot survey/focus group discussion. The reliability of the questionnaire was ascertained by trial testing with 15 farmers in each state and internal consistency was achieved using Cronbach Alpha reliability technique. This was to help validate the questions and check the information to be supplied later by individual farmers. A farmer-to-farmer visit was next undertaken to collect data, which included farm households' levels of vulnerability to disaster based on human, economic and institutional capacity of farmers in coping with floods on gender basis. The data were analyzed using United Nations Vulnerability Index.

\section{Estimation Procedures}

\section{Vulnerability Index (VI) Analysis}

To achieve the objective, which aimed at assessing farmers' vulnerability to the effects of flood, vulnerability analysis was employed. Using household adaptive capacity approach, data were collected on human, economic and institutional capacity of farmers in coping with flood problems on gender basis. The data collected were arranged in the form of a rectangular matrix with rows representing gender of household head and columns representing indicators. Thus, vulnerability is potential impact (1) minus adaptive capacity $(A C)$.

This leads to the following mathematical equations for vulnerability.

$$
V=f(1-A C)
$$




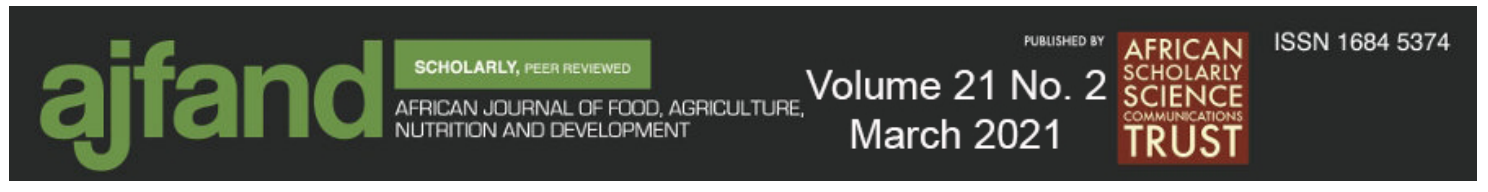

Indicators of Vulnerability

$\begin{array}{cccc}\text { Gender of HHOLD Head } & \mathbf{1} & \mathbf{2} & \mathbf{K} \\ \text { MHHD } & X i j 1 & X i j 2 & X i j k \\ \text { FHHID } & X i j 1 & X i j 2 & X i j k\end{array}$

The obtained data from the estimated vulnerability indicators (adaptive features) as used in this study were normalized to be free from their respective units so that they all lie between 0 and 1 . The decision rule is that a household whose vulnerability index is less than or equal to 0.05 is considered not vulnerable while a household with vulnerability index of greater than 0.05 is vulnerable to natural disasters. The gender with the higher value corresponds to high vulnerability and vice versa. Hence, the normalization was achieved with this formula following United Nation Development Programme in assessing Human Development Index:

$i j=\frac{\operatorname{Max}\{X i j\}-(X i j)}{\operatorname{Max}\{X i j\}-\operatorname{Min}\{X i j\}}$.

Where:

$X_{i j}$ represents the value of the vulnerability indicator for the farm household $m$ represents gender of Household head

Max \& Min represent maximum and minimum values of indicators respectively.

$\mathrm{K}=$ represents the number of indicators used

The vulnerability indicators that were used to measure adaptive capacity of farm households in flood prone areas of south-east Nigeria include:

$\mathrm{XI}=$ Farming income (in Naira)

$\mathrm{X} 2=$ Years of formal education (in years)

$\mathrm{X} 3=$ Farm size (in ha)

$\mathrm{X} 4$ = Land ownership status (Communal/Family) (Yes or No)

$\mathrm{X} 5=$ Personal land ownership status (Yes/No)

$\mathrm{X} 6=$ Rent land ownership status $(\mathrm{Yes} / \mathrm{No})$

$X 7=$ Number of farm labourers (number of persons)

$\mathrm{X} 8=$ Number of extension contacts (number of visits)

X9 $=$ Access to farm credits or loan (Yes or No)

$\mathrm{X} 10=$ Access to weather information (Yes or No)

$\mathrm{X} 11=$ Access to remittances (Yes or No)

$\mathrm{X} 12=$ Membership of cooperative (Yes or No)

$\mathrm{X} 13$ = Assistance from National Emergency Management Agency/ State Emergency Management Agency (Yes or No)

$\mathrm{X} 14$ = On-going insurance coverage (Yes or No) 


\section{RESULTS AND DISCUSSION}

\section{Gender-based Vulnerability to Extreme Weather events among Farm Households in South-east Nigeria}

The results presented in Table1 showed gender-based vulnerability to the impact of flood using adaptive capacity approach in the area. The adaptive indicators assessed were years of education, farm size, farmland ownership status of the farmer, farm income, extension visits, access to credit, membership of cooperative, access to weather information, remittance to support farming, assistance from NEMA/SEMA and access to ongoing-insurance coverage showed that increases in adaptive indicators result in increased coping capacity of households, which consequently reduce their vulnerability. Therefore, the adaptive indicators assessed in this study are supposed to have negative or inverse functional relationship with vulnerability.

Using education of the household head as indicator, male-headed households with a vulnerability index of 0.64 were slightly more vulnerable to extreme weather events than female-headed households that had a corresponding vulnerability index of 0.61. Education predisposes them to better adaptive capacity approach to extreme weather events and also assistance they also get from institutions like the National Emergency Management Agency. This agreed with the study of Enete et al. [7] and the report of Benhin [8], that the level of education of the farmers is a major determinant of their speed of adoption of climate change adaptation measures.

Considering farm size, male-headed households had low vulnerability index of 0.13 compared to female-headed households with vulnerability index of 0.65 . Larger farm size plays a critical role in adaptive capacity approach because different varieties of crop could be planted by the same farmer, some which are flood resistant crops. The findings agreed with the study of Enete et al. [9] that indicates that male-headed households operated larger farm size in the area, which could possibly enhance their adoption of varieties of adaptation strategies to cope with extreme weather events than their female counterparts.

On the land ownership status, considering communal/ family land, male-headed households had a vulnerability index of 0.50 and their female counterparts had 0.68 , while on personal ownership status (that is land not inherited or rented rather bought by the owner) male-headed households had a vulnerability index of 0.19 , while their female counterparts had 0.59 and on rent ownership status male-headed households had a vulnerability index of 0.44 , while their female counterparts had 0.34 . The foregoing suggests that male-headed households had more access to land, which could possibly enhance their adaptive capacity approach with extreme weather events than females. Fabiyi et al. [10] reported that women in Nigeria rarely own land despite their heavy involvement in agriculture. The findings of this study agreed with the study of Ogada et al. [11] that secure land tenure had a positive influence on the probability of adopting terrace as a farm technology in the rain-fed semi-arid lands of Kenya. It was reported by Birrugi and Hassan [12] that land tenure security increases the probability of investment in land management as a coping strategy. 


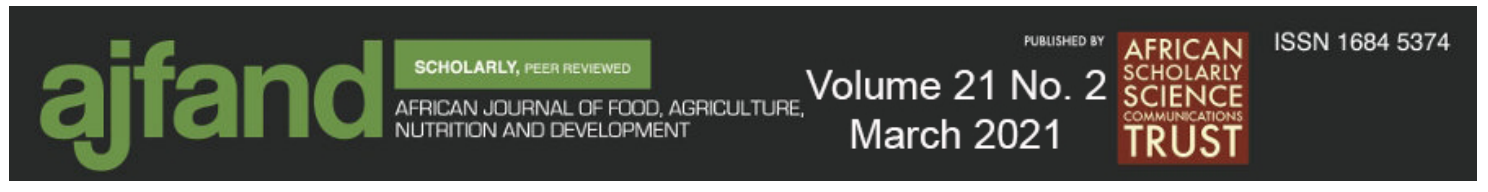

Using availability of farm labour, male-headed households had vulnerability index of 0.38 , while female-headed households had 0.83. Larger farm labour also implies larger farm size with more flood resistant crops. The low vulnerability index of male-headed households indicated that they were more endowed with farm labour than femaleheaded households, which enhances their adaptation strategy.

Using number of extension visits/contacts as adaptive indicator, male-headed households had a vulnerability index of 0.63 while their female counterparts had vulnerability index of 0.64 . The results showed that both male- and female-headed households had almost equal access to extension training for improved adaptive knowledge. This disagreed with the report of Rafferty [13] that agricultural extension programmes and other support services had traditionally focused more on educating male farmers than women, hence women farmers largely depended on their husband for information on farm input and other resources necessary for farm decision making.

The vulnerability index of male-headed households under access to credit was 0.35 while that of the female-headed households was 0.43 . The low vulnerability index of male-headed households indicated higher access to farm credits, which in turn enhanced their adaptive capacity to natural disaster menace. The findings of the study carried out by Enete and Amusa [7] showed that farmers' access to farm credit and loan enhances adaptation to new technology and climate change as access to cash allows farmers to purchase inputs like seeds of improved varieties and fertilizers.

On access to weather information, male-headed households had a vulnerability index of 0.30 , while their female counterparts had a slightly higher value of 0.36 . The results showed both had access to almost the same level of weather information, which enhances their adaptive capacity. Adaptive capacity measured by their level of information they get from Nigerian Meteorological Agency help them to change date of planting in order to mitigate the negative effects of extreme weather events.

Using household access to remittance as a measure of natural disaster coping capacity, the vulnerability index of male-headed household was 0.12 , while that of femaleheaded households was 0.68 . This could be deduced from the fact that household migrants are more committed in giving remittances to their fathers for building projects and part of the remittance channeled to agricultural activities [12].

Regarding membership of farmers' cooperative as an adaptive capacity indicator, maleheaded households had vulnerability index of 0.53 compared to 0.63 for female-headed households. This indicated that male-headed households were more organized into farmers' cooperative societies in the area than their female counterparts. Many farmers are resource-poor, and as such cannot meet most of their needs independently. Therefore, their coming together in cooperatives affords them the opportunity to pool resources together to solve common challenges facing their farms. It also makes it easier for them to access and to be accessed by government agencies in order to inform or assist them in their farm operations. This result is in agreement with Anyaoha et al. [14] and Balew et al. [15] who reported that membership of cooperative societies positively affected climate change adaptation among farmers in Umuahia South Local 


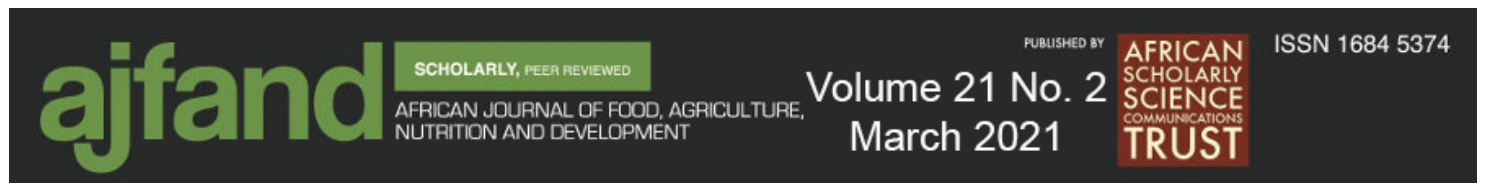

Government Area of Abia State, Nigeria and some regions in Central Ethiopia, respectively.

On the assistance from NEMA/SEMA, male-headed households had lower vulnerability index of 0.44 , while their female counterparts had a vulnerability index of 0.60 . The adaptive capacity of male-headed households measured by assistance they get more from the agencies could account for their lower vulnerability index.

Regarding on-going insurance coverage, male-headed households had a slightly higher vulnerability index of 0.49 than their female counterparts with 0.44 . It could be that insurance education is more effective for women and also women are more risk conscious, more careful people by nature and are more convinced to go into insurance scheme. Therefore, women in the sample are more confident with insurance system.

On farming income of the farmers, the vulnerability index of male-headed households was as low as 0.30 , while that of female-headed households was 0.96 . This implied that male-headed households had higher farming income and possibly increased adaptive capacity to employ more natural disaster management strategies to cope with the challenges of natural disaster than their female counterparts. This finding corroborated the report of Agabi [16] that, increase in farmers' income in north central Nigeria increased coping capacities among the farmers.

Overall, using household adaptive capacity approach, which is a function of the available institutional, human and material resources, to cope with the effects of natural disasters, the results of the gender-based vulnerability analysis showed male-headed farming households with a vulnerability index of 0.38 , while the female-headed farming households, on the other hand had 0.68. This finding is in line with that of Babatude et al. [17] who assessed gender-based determinants of vulnerability to food insecurity among farming households in Nigeria and found that male-headed households possessed more resources than female-headed households. The authors reported further that crop output, off-farm income, total household income and available labour were significantly higher in male-headed households than in femaleheaded households. The report of USAID [18] showed that women who constitute the major food producers in developing countries generally had lower incomes, less access to credit and limited control over resources resulting in their increased vulnerability to many natural disaster impacts. In addition, Olorunsanya and Omotesho [19] found that female-headed households are more poverty prone than male-headed farming households in North-central Nigeria. Extreme weather event is indeed a global phenomenon especially as it affects the vulnerable groups in poor countries such as Nigeria. This is especially because adaptation is a big issue for poor countries (example, in sub-Saharan Africa that has very similar socio-economic characteristics) with very low capacity to adapt, such that knowledge from one can be adapted in another.

The results of t-test statistics in Table 3 showed that the p-values (significant) on three variables, specifically plot size, remittance and income are $0.04,0.03$ and 0.01 , respectively, which are in each case less than 0.05 level of significance. This implied 


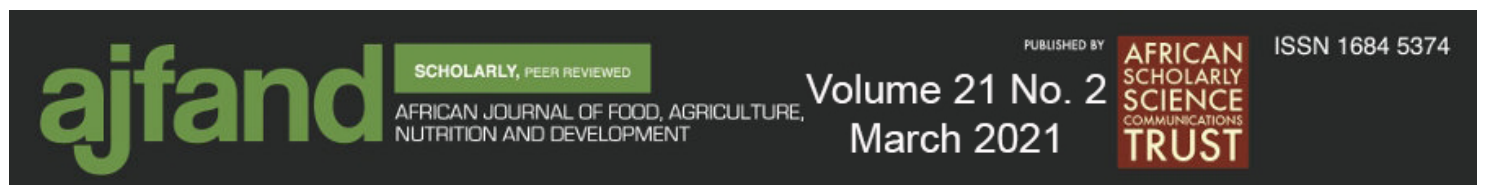

that there are significant differences in the mean vulnerabilities of male- and femaleheaded households with regards to plot size, remittance and income. The differences on the other variables were not significant hand. The p-value of the summary (pooled) was 0.02 , which was less than 0.05 level of significance. This indicates that there was significant difference in the mean vulnerabilities of male- and female-headed households to extreme weather events in South-east Nigeria in favour of male-headed households. This finding is in line with that of Enete and Amusa [7] who found that, using household adaptive capacity approach, female-headed farming households in south-western Nigeria were more vulnerable to effects of climate change than their male counterparts. In addition, the findings of the study conformed to the result of Babatunde, Omotesho, Olorunsanya and Owotoki [17] that assessed gender-based determinants of vulnerability to food insecurity among farming households in Nigeria and found that male-headed households possessed more resources than female-headed households.

\section{CONCLUSION}

Female-headed farm households were more vulnerable than their male-headed counterparts, although the farming households were all generally highly vulnerable to the incidence of extreme weather events such as flooding, erosion and extreme heat because of low adaptive capacity. We recommend that efforts to address climate adaptation among farmers should be gender sensitive. 


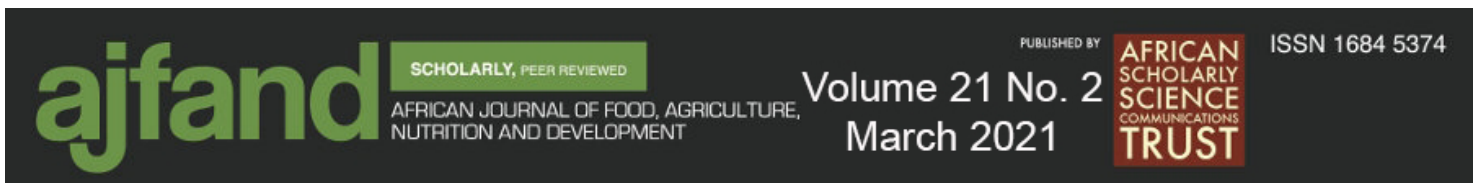

Table 1: Adaptive Capacity Assessment of Gender-based Vulnerability of Farmers to Extreme Weather events in South-east Nigeria $(N=240)$

\begin{tabular}{|c|c|c|c|c|c|c|c|c|c|c|}
\hline \multirow[b]{2}{*}{$\mathbf{S N}$} & \multirow[b]{2}{*}{ Adaptive Indicators } & \multirow[b]{2}{*}{ Gender } & \multicolumn{2}{|c|}{ Anambra } & \multicolumn{2}{|c|}{ Enugu } & \multicolumn{2}{|l|}{ Ebonyi } & \multicolumn{2}{|c|}{ Average } \\
\hline & & & $\begin{array}{l}\text { Actual } \\
\text { Value }\end{array}$ & $\begin{array}{l}\text { Vul. } \\
\text { Index }\end{array}$ & $\begin{array}{l}\text { Actual } \\
\text { Value }\end{array}$ & $\begin{array}{l}\text { Vul. } \\
\text { Index }\end{array}$ & $\begin{array}{l}\text { Actual } \\
\text { Value }\end{array}$ & $\begin{array}{l}\text { Vul. } \\
\text { Index }\end{array}$ & $\begin{array}{l}\text { Actual } \\
\text { Value }\end{array}$ & $\begin{array}{l}\text { Vul. } \\
\text { Index }\end{array}$ \\
\hline \multirow[t]{2}{*}{$\mathrm{X} 1$} & EDUCATION & MHНD & 4.5897 & 1.00 & 13.2857 & 0.00 & 5.1818 & 0.93 & 7.6857 & 0.64 \\
\hline & & FHHD & 6.3658 & 0.79 & 11.8222 & 0.17 & 5.7659 & 0.86 & 7.9846 & 0.61 \\
\hline \multirow[t]{2}{*}{$\mathrm{X} 2$} & PLOT SIZE & МНHD & 2.6538 & 0.00 & 2.5114 & 0.35 & 2.6363 & 0.04 & 2.6005 & 0.13 \\
\hline & & FHHD & 2.4634 & 0.47 & 2.2511 & 1.00 & 2.4574 & 0.49 & 2.3906 & 0.65 \\
\hline \multirow[t]{2}{*}{$\mathrm{X} 3$} & $\begin{array}{l}\text { COMMUNAL/FAMIL } \\
\text { Y LAND }\end{array}$ & MHHD & 0.2820 & 0.80 & 0.9142 & 0.00 & 0.3636 & 0.70 & 0.5199 & 0.50 \\
\hline & & FHHD & 0.1951 & 0.91 & 0.8222 & 0.12 & 0.1276 & 1.00 & 0.3816 & 0.68 \\
\hline \multirow[t]{2}{*}{$\mathrm{X} 4$} & PERSONAL LAND & MHHD & 0.7435 & 0.03 & 0.4857 & 0.53 & 0.7575 & 0.00 & 0.6622 & 0.19 \\
\hline & & FHHD & 0.5317 & 0.45 & 0.2444 & 1.00 & 0.5046 & 0.34 & 0.5735 & 0.59 \\
\hline \multirow[t]{2}{*}{$\mathrm{X} 5$} & RENT LAND & MHHD & 0.7179 & 0.10 & 0.2857 & 1.00 & 0.6666 & 0.21 & 0.5567 & 0.44 \\
\hline & & FHHD & 0.7073 & 0.13 & 0.3333 & 0.90 & 0.7659 & 0.00 & 0.6021 & 0.34 \\
\hline \multirow[t]{2}{*}{$\mathrm{X} 6$} & HOUSEHOLD SIZE & MHНD & 6.7948 & 0.00 & 6.4000 & 0.66 & 6.5151 & 0.47 & 6.5699 & 0.38 \\
\hline & & FHHD & 6.1951 & 1.00 & 6.3111 & 0.81 & 6.3829 & 0.68 & 6.2963 & 0.83 \\
\hline \multirow[t]{2}{*}{$\mathrm{X} 7$} & EXTENSION VISITS & MHHD & 7.8461 & 1.00 & 14.3428 & 0.00 & 8.5151 & 0.89 & 10.2346 & 0.63 \\
\hline & & FHHD & 9.5853 & 0.73 & 12.1777 & $\mathbf{0 . 3 3}$ & 8.7446 & 0.86 & 10.1692 & 0.64 \\
\hline \multirow[t]{2}{*}{$\mathrm{X} 8$} & CREDIT ACCESS & MHHD & 0.7179 & 0.00 & 0.2857 & 1.00 & 0.6969 & 0.05 & 0.5668 & 0.35 \\
\hline & & FHHD & 0.6097 & 0.25 & 0.3333 & 0.89 & 0.6595 & 0.14 & 0.5341 & 0.43 \\
\hline \multirow[t]{2}{*}{$\mathrm{X} 9$} & $\begin{array}{l}\text { WEATHER } \\
\text { INFORMATION }\end{array}$ & MHHD & 0.9230 & 0.03 & 0.2857 & 0.79 & 0.8787 & 0.07 & 0.6958 & 0.30 \\
\hline & & FHHD & 0.8780 & 0.07 & 0.1111 & 1.00 & 0.9361 & 0.00 & 0.6417 & 0.36 \\
\hline \multirow[t]{2}{*}{$\mathrm{X} 10$} & REMITTANCE & MHHD & 0.4871 & 0.17 & 0.5142 & 0.00 & 0.4848 & 0.19 & 0.4953 & 0.12 \\
\hline & & FHHD & 0.4390 & 0.48 & 0.3555 & 1.00 & 0.4255 & 0.56 & 0.4066 & 0.68 \\
\hline \multirow[t]{2}{*}{$\mathrm{X} 11$} & $\begin{array}{l}\text { COOPERATIVE } \\
\text { MEMBERSHIP }\end{array}$ & MHHD & 0.5897 & 0.53 & 0.6000 & 0.49 & 0.5757 & 0.58 & 0.5884 & 0.53 \\
\hline & & FHHD & 0.4634 & 1.00 & 0.7333 & 0.00 & 0.4893 & 0.90 & 0.5620 & 0.63 \\
\hline \multirow[t]{2}{*}{$\mathrm{X} 12$} & $\begin{array}{l}\text { NEMA/SEMA } \\
\text { ASSISTANCE }\end{array}$ & MHHD & 0.9743 & 0.00 & 9.9844 & 0.37 & 0.0993 & 0.95 & 3.6860 & 0.44 \\
\hline & & FHHD & 0.9024 & 0.10 & 0.9432 & 0.70 & 0.0851 & 1.00 & 0.6435 & 0.60 \\
\hline \multirow[t]{2}{*}{$\mathrm{X} 13$} & $\begin{array}{l}\text { INSURANCE } \\
\text { COVERAGE }\end{array}$ & MHHD & 0.3333 & 0.39 & 0.0857 & 0.87 & 0.4242 & 0.21 & 0.2810 & 0.49 \\
\hline & & FHHD & 0.3658 & 0.33 & 0.0222 & 1.00 & 0.5319 & 0.00 & 0.3066 & 0.44 \\
\hline \multirow[t]{2}{*}{$\mathrm{X} 14$} & INCOME & MHHD & 582641 & 0.40 & 620000 & 0.00 & 572515 & 0.51 & 591718 & 0.30 \\
\hline & & FHHD & 527073 & 1.00 & 535755 & 0.91 & 531000 & 0.96 & 531276 & 0.96 \\
\hline
\end{tabular}




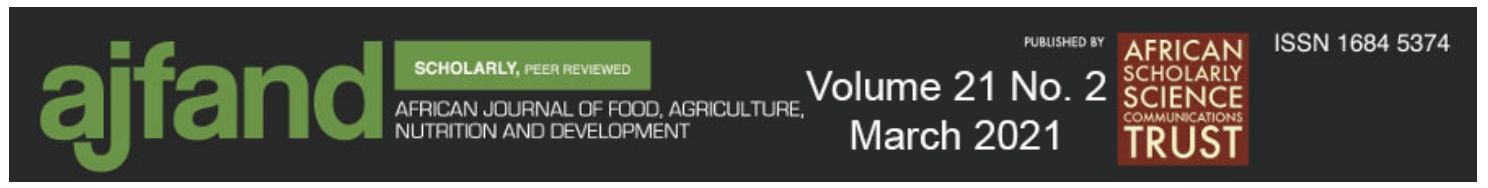

Table 2: Overall Vulnerability Index (V.I)

\begin{tabular}{ll}
\hline $\begin{array}{l}\text { Gender-based Vulnerability to } \\
\text { Extreme Weather Events }\end{array}$ & Vul. Index \\
\hline MHHD & $\mathbf{0 . 3 8}$ \\
FHHD & $\mathbf{0 . 6 0}$ \\
& \\
State-based Vul. to Natural Disaster & Vul. Index \\
Anambra State & $\mathbf{0 . 4 3}$ \\
Enugu State & $\mathbf{0 . 5 7}$ \\
Ebonyi State & $\mathbf{0 . 4 8}$ \\
\hline
\end{tabular}

Note: $\quad$ MHHD $=$ Male-Headed Household

FHHD $=$ Female-Headed Household

Source: Computed from Field Survey 


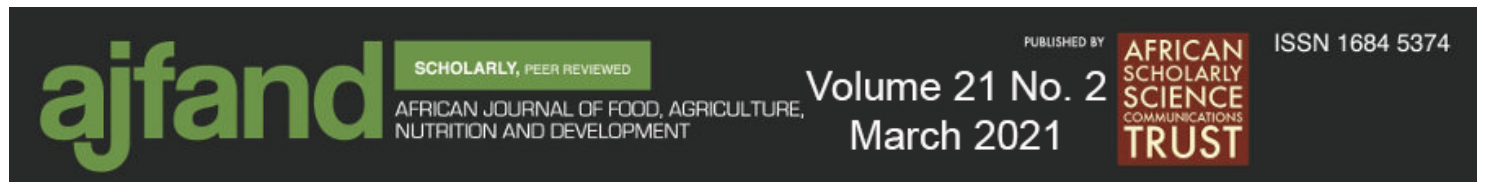

Table 3: Results of t-test Statistics of significance difference in vulnerability of male- and female-headed households Extreme Weather events in Southeastern Nigeria $(N=\mathbf{2 4 0})$

\begin{tabular}{|c|c|c|c|c|c|c|}
\hline $\mathbf{S N}$ & Variables & Gender & $\overline{\mathbf{X}}$ & SD & $\begin{array}{l}\text { Std. } \\
\text { Error }\end{array}$ & $\begin{array}{c}\text { p-value } \\
\text { Sig. }\end{array}$ \\
\hline \multirow[t]{2}{*}{1} & Education & MHHD & 0.64 & 0.55 & 0.38 & 0.93 \\
\hline & & FHHD & 0.60 & 0.37 & & \\
\hline \multirow[t]{2}{*}{2} & Plot size & MHНD & 0.13 & 0.19 & 0.20 & $0.04 *$ \\
\hline & & FHHD & 0.65 & 0.30 & & \\
\hline \multirow[t]{2}{*}{3} & Communal/family land & MHHD & 0.50 & 0.43 & 0.37 & 0.66 \\
\hline & & FHHD & 0.67 & 0.48 & & \\
\hline \multirow[t]{2}{*}{4} & Personal land & MHHD & 0.18 & 0.29 & 0.26 & 0.19 \\
\hline & & FHHD & 0.59 & 0.35 & & \\
\hline \multirow[t]{2}{*}{5} & Rent & MHHD & 0.43 & 0.49 & 0.39 & 0.82 \\
\hline & & FHHD & 0.34 & 0.48 & & \\
\hline \multirow[t]{2}{*}{6} & Household size & MHHD & 0.37 & 0.33 & 0.21 & 0.10 \\
\hline & & FHHD & 0.83 & 0.16 & & \\
\hline \multirow[t]{2}{*}{7} & Extension visits & MHHD & 0.63 & 0.54 & 0.35 & 0.97 \\
\hline & & FHHD & 0.64 & 0.27 & & \\
\hline \multirow[t]{2}{*}{8} & Credit access & MHHD & 0.35 & 0.56 & 0.40 & 0.85 \\
\hline & & FHHD & 0.42 & 0.40 & & \\
\hline \multirow[t]{2}{*}{9} & Weather information & MHHD & 0.29 & 0.42 & 0.40 & 0.89 \\
\hline & & FHHD & 0.35 & 0.55 & & \\
\hline \multirow[t]{2}{*}{10} & Remittance & MHHD & 0.12 & 0.10 & 0.17 & $0.03 *$ \\
\hline & & FHHD & 0.68 & 0.28 & & \\
\hline \multirow[t]{2}{*}{11} & Corporative membership & MHНD & 0.53 & 0.04 & 0.31 & 0.77 \\
\hline & & FHHD & 0.63 & 0.55 & & \\
\hline \multirow[t]{2}{*}{12} & NEMA/SEMA assistance & MHHD & 0.44 & 0.47 & 0.38 & 0.69 \\
\hline & & FHHD & 0.60 & 0.45 & & \\
\hline \multirow[t]{2}{*}{13} & Insurance coverage & MHHD & 0.49 & 0.34 & 0.35 & 0.90 \\
\hline & & FHHD & 0.44 & 0.50 & & \\
\hline \multirow[t]{4}{*}{14} & Income & MHHD & 0.30 & 0.26 & 0.15 & $0.01 *$ \\
\hline & & FHHD & 0.95 & 0.04 & & \\
\hline & SUMMARY (Pooled) & МНHD & 0.38 & 0.06 & 0.06 & $0.02 *$ \\
\hline & & FHHD & 0.60 & 0.08 & & \\
\hline
\end{tabular}

Note: $\quad$ MHHD $=$ Male-Headed Household FHHD $=$ Female-Headed Household $*=$ Significant at $\mathrm{p} \leq 0.05$

Source: Field Survey, 2018 


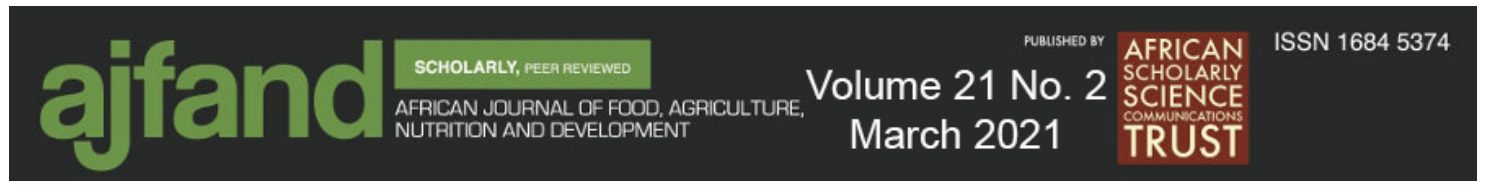

\section{REFERENCES}

1. Food and Agricultural Organization [FAO]. Joint Assessment Report on Flood Damage and Loss for Agriculture and Food Security Response and Rehabilitation. Abuja, Nigeria 2012.

2. Holzmann R and S Jorgensen Social Protection Social Risk Management: Conceptual Underpinnings for the Social Protection Sector Strategy Paper. Journal of International Development 2000; 1: 1005-27.

3. IPCC.Climate Change Impacts, Adaptation and Vulnerability. Contribution of Working Group II to the Fourth Assessment Report of the Intergovernmental Panel on Climate Change. London: Cambridge University Press 2007.

4. Anthony C Climate Change Impacts on Different Agro-ecological Zones of West Africa Humid Zones. Progress in Development Studies 2009; 4(3): 13-17.

5. Von-Braun J Director General, International Food Policy Research Institute Draft, Washington D.C., USA 2008.

6. National Population Commission [NPC]. National Population Distribution Figures in Nigeria (2020).

7. Enete AA and TA Amusa Determinants of Women's Contribution to Farming Decisions in Cocoa-Based Agroforestry Households of Ekiti State, Nigeria. Field Actions Science Reports (FACTS) 2010; Vol. (4) 1: 1- 6.

8. Benhin JKA Climate change and South African agriculture: Impacts and adaptation options. CEEPA Discussion paper No. 21, CEEPA, University of Pretoria, South Africa 2006.

9. Enete AA, Obi JN, Ozor N and CL Mba "Socio-economic assessment of flooding among farm households in Anambra state, Nigeria", International Journal of Climate Change Strategies and Management 2016; Vol. 8 Issue:1:96-111, https://doi.org/10.1108/IJCCSM-07-2014-0084

10. Fabiyi EF, Danladi BB, Akande KE and Y Mahmood Role of women in Agricultural Development and their constraints: A Case Study of Biliri Local Government Area of Gombe State, Nigeria. Pakistan Journal of Nutrition 2007; 6 (6): $676-680$.

11. Ogada MJ, Nyaangena $\mathbf{W}$ and $M$ Yusuf Production Risk and Farm Technology Adoption in the Rain-Fed Semi-arid Lands of Kenya. AFJARE 2010;4(2): $159-174$.

12. Birungi $\mathbf{P}$ and $\mathbf{R}$ Hassan Poverty, property rights and land management in Uganda. African Journal of Agricultural and Resource Economics 2010; 4(1): 48-69. 


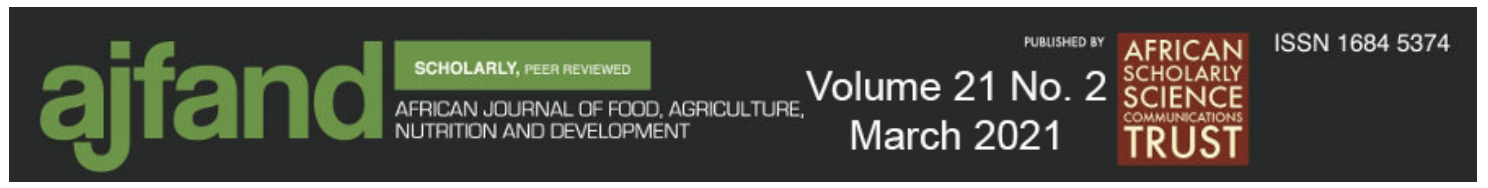

13. Raffety $\mathbf{M}$ The Roles of Women in Economic Development in Tanzania. London: Printer Publishers Ltd 1998: 122-129.

14. Anyaoha NO, Nnadi FN, Chikaire J, Echetama JA, Utazi CO and RA Ihenacho Socio-economic factors influencing climate change adaptation among crop farmers in Umuahia South Area of Abia State, Nigeria. Net Journal of Agricultural Science 2013; 1(2): 24 - 47.

15. Balew S, Agwata $\mathbf{J}$ and $\mathbf{S}$ Anyango Determinants of adoption choices of climate change adaptation strategies in crop production by small scale farmers in some regions of central Ethiopia. Journal of Natural Sciences Research 2014; 4(4): 78-93.

16. Agabi B M The perception and Adaptation to Climate Change among Rural Farmers in North- Central Nigeria. Middle East Journal of Environmental Research 2012; 5 (2): 338 - 352.

17. Babatunde RO, Omotesho OA, Olorunsanya EO and GM Owotoki Determinants of Vulnerability to food insecurity: A gender-based analysis of farming households in Nigeria. Indian Journal of Agricultural Economics 2008;63(1): $116-125$.

18. United State Agency for International Development [USAID]. Fact Sheet: Climate Change and Gender United State 2010.

19. Olorunsanya EO and OA Omotesho A gender analysis of poverty profile of rural farming households in North Central, Nigeria 2011. 